\title{
Supporting Smallholders to Access Sustainable Supply Chains: Lessons from the Indian Cotton Supply Chain
}

\author{
Laia Fayet ${ }^{1 *}$ and Walter J.V. Vermeulen ${ }^{2 * * *}$ \\ ${ }^{1}$ Researcher, MSc in Sustainable Development Intern Copernicus Institute of Sustainable Development, Utrecht, \\ the Netherlands \\ ${ }^{2}$ Utrecht University, Faculty of Geosciences, Copernicus Institute of Sustainable Development, Utrecht, the Netherlands
}

\begin{abstract}
A significant number of different sustainable initiatives have emerged to improve sustainability and inclusion of small farmers in global supply chains. These include production process adjustment advice and implementation of different sustainable product standards. In practice two different approaches are taken. Development projects focus on enabling farmers to adjust their practices to Organic, Fairtrade and other standards requirements. In international trade, buyers from developed countries implement separate supply chain assurance systems. This article presents nine case studies of practices from both approaches in the cotton supply chain in India.

The results show improvements in the livelihoods of small farmers but increased market access depends on what approaches are used. The future challenge is to combine the different approaches, creating market links and enhancing supply chain efficiency while providing development support at community levels. With such a balance it will be possible to assure project sustainability and maximize long-term economical, environmental and social benefits. Copyright (C) 2012 John Wiley \& Sons, Ltd and ERP Environment
\end{abstract}

Received 28 November 2011; revised 4 April 2012; accepted 17 April 2012

Keywords: corporate social responsibility; cotton; India; private standards; self-regulation; smallholders; stakeholder engagement, sustainable development; supply chain governance

\section{Introduction}

INCE THE 1980S, GLOBAL TRADERS AND PRODUCERS HAVE BEEN PRESSURED BY INTERNATIONAL INSTITUTIONS, governments, non-governmental organizations (NGOs), customers and also internally by managers and employees to improve the sustainability of their outputs. New responsible business practices have been demanded to reduce the environmental and social impacts of production and share responsibility

\footnotetext{
*Correspondence to: Laia Fayet, Senior Business Management and CSR consultant, Ingeniería Social, Barcelona, Spain. E-mail: laia.fayet@gmail.com 
with their business partners along the full product supply chain (Raynolds et al., 2007; Cramer, 2008; Vermeulen and Seuring, 2009).

As a result of these pressures, companies had to change the way they previously operated to maintain their competitive advantage in the global markets (Alberto, 2009; Porter and Kramer, 20II). Sustainable business and corporate social responsibility have emerged, emphasizing and encouraging strict environmental and social business performance standards. Within the international sourcing processes, corporate responsibility focuses on sustainable supply chain management, which coordinates demand needs towards the suppliers along the supply chain, addressing both economic aspects as well as social and environmental aspects (Seuring and Müller, 2007).

In the last decade, there has been a rapid increase in the number of voluntary certification and labelling initiatives addressing environmental and social supply chain issues. Early certification initiatives emerged in the i98os, usually initiated by NGOs. Fairtrade and Organic products certification were developed in niche markets. They attempted to directly link small producers in developing countries with western consumers, securing product quality and its environmental or social responsibility (Vermeulen and Seuring, 2009). At the same time, better and fair prices, stable employment, and partnership relations were promoted for small producers in developing countries.

Companies started joining these certification schemes to increase their market share and capitalize on new opportunities and trends. At the same time, these initiatives offer producers the possibility of increasing control over their supply chains, thereby assuring safety and quality standards (Raynolds et al., 2007) while reducing production costs. Certification also delivered positive side-effects, including enhanced reputation and trust from consumers and other stakeholders.

Since 2000, interest in sustainability issues has increased rapidly. Sustainable chain governance systems have arisen in the form of cooperation among various market and non-market actors to improve the environmental and social conditions of production operations in developing countries (Vermeulen and Ras, 2006; Vermeulen, et al., 2010). With this approach, market actors and NGOs have been filling a 'regulatory vacuum' created by globalization and state deregulation (Raynolds et al., 2007). These new forms of self-regulation, which can be single-firm approaches, joint product sector or cross-sectoral, apply third-party certification auditing to assure that their practices and products can be labelled as environmentally and socially responsible (Vermeulen, 20Io). These three different approaches, and the various forms of interaction and actors involved, operate on the premise that business-tobusiness supply chain cooperation can improve environmental and social conditions in developing countries under the pressure guidelines of civil society and consumers (Vermeulen and Seuring, 2009).

The ability of business-to-business and NGO-to-business market interventions to address smallholders' vulnerability has been pointed out by various authors (Bacon, 2005; Parrish et al., 2005; MacDonald 2007). The primary positive outcomes include reduction of commodity-price vulnerability and an increase in farmer revenues, skills and organizational capabilities. However, the degree to which these desired positive outcomes are achieved is dependent upon the certification schemes and on the techniques used to put them in place (Bolwig et al., 2009; Valkila and Nygren, 2009).

Even though market actors have the power to address and enforce the promotion of more environmentally and socially responsible practices by setting sustainable performance requirements for their suppliers, such efforts are not always successful and can sometimes cause negative side-effects. Unintended negative effects on smallholders wishing to access global supply chains include:

- homogenization of the supply chain, benefiting a small number of expert firms to the detriment of small farmers (Ito, 2004; Gonzalez and Nigh, 2005; Francesconi et al., 2010);

- unfair trading practices that transfer risks and transaction costs to the supply side (Freidberg, 2003; Ras et al., 2007; Ras and Vermeulen, 2009; Riisgaard et al., 2010);

- unequal access to decision-making and ignorance of local socioeconomic structures and needs (Blowfield, 2003; Freidberg, 2003; Gonzalez and Nigh, 2005; Ponte, 2008; Alberto, 2009; Beuningen and Knorringa, 2009; Muller et al., 2009; Hall and Matos, 2010; Muller et al., 2012).

These side-effects challenge the assumed economic, social and environmental benefits of certification via the market mechanism. Further insights on how smallholder participation can be enhanced using sustainable supply chain governance systems are therefore needed. In this article we analyze current initiatives and their outcomes, using examples from the Indian cotton supply sector to answer several key questions: 
- How can market-based and/or development-NGO initiatives ensure smallholder participation in sustainable global supply chains?

- What initiatives are already in place to address smallholder exclusion?

- What are the opportunities and barriers of such initiatives?

The first goal of this article is to identify and describe various approaches, including different implementation and certification mechanisms that are trying to improve smallholders' participation in sustainable supply chain governance systems. The second goal is to identify which initiatives and key stakeholders are in place. The third goal is to evaluate at field level the impact of the different initiatives and to gather lessons on best practices and challenges.

In Section 2 we explain our research approach and in Section 3 we discuss the challenges and inclusion mechanisms for smallholders. In Section 4 we present an overview on how the cotton chain can improve its sustainability. Then in Section 5 we compare the different practices performed and identify lessons learned and challenges to be overcome. Finally we reflect on the findings and recommend further steps.

\section{Research Approach}

This study has an exploratory character. It focuses on a specific product chain, the cotton chain, and a specific country, India, to identify the initiatives, opportunities and barriers to improve smallholder access to international sustainable supply chains.

Extensive exploratory interviews (Appendix A) and final mapping of the different initiatives were performed to create a complete overview of which frontrunner initiatives are in place within the cotton supply chain in India, identifying key stakeholders and major players.

To assess the impacts and challenges of the different smallholder engagement initiatives at field level, the study employed multiple descriptive case studies. The case study method was chosen because it allows the exploration of the performance of different initiatives given the environment, actors and communities within which they actually operate. Basic rules of case study preparation, including checklists and data triangulation, were applied (Yin, 2003; Seuring, 2008).

The nine selected cases represent different sustainable cotton standards as well as diverse implementation approaches. In each case study, relevant Indian and European partners were interviewed about their motivations for participation, the mechanisms used to enhance smallholder inclusion, their opinions on factors contributing to success, potential barriers to success and project results (Appendix B). In five of the nine cases, additional information was gathered through interviews with smallholder farmers. They were asked about their situations before the initiatives, about collaboration and training during the implementation, and about challenges and accomplishments. Finally, market partners, such as ginners and textile manufacturers, were also interviewed.

\section{Smallholder Participation in Value Chains: Challenges and Inclusion Mechanisms}

Linking small producers to markets and integrating them into value chains is widely recognized as a valuable way to reduce poverty. However, little is known about the precise conditions under which this is most likely to occur.

Smallholders are often illiterate, under-educated, lack management and technical skills, and have poor access to information (about quality, buyer demand and standards). Their organization and access to markets is also limited. They are therefore at a disadvantage compared with large commercial farmers who can supply larger quantities of product and can guarantee product quality. Larger farmers have more bargaining power and better access to capital, information, finance and technology. In addition, smallholders' transaction costs are usually higher because they are geographically dispersed and have poor infrastructure, including transport and communications (Parikh et al., 2007; Ashley and Mitchell, 2008; Ponte, 2008; Proctor and Digal, 2008; Belton et al., 2009; Beuningen and 
Knorringa, 2009; Devaux et al., 2009; Ras and Vermeulen, 2009; Alexander et al., 20Io; Elzakker and Eyhorn, 20I0; Hall and Matos, 20I0; Magnus and Steenhuijsen, 20I0; Markelova and Mwangi, 20I0)

Both new and traditional mechanisms that address the negative effects of applying for certification and that try to overcome smallholder barriers to access international supply chains have been identified in different literature sources. We classify these different inclusion mechanisms into two main groups: reorganizing the value chain and enhancing smallholders' capabilities. Both include various activities.

\section{Reorganizing the Value Chain}

a. Supply Chain Shortcuts and Upgrading

Shortening the value chain can benefit small by reducing the number of intermediates along the supply chain thereby increasing profit for smallholders. Upgrading strategies aim to move producers up into the value chain either by adding value to their products by adding value to their processes or by acquiring new functional positions (Laven, 2009; Riisgaard et al., 2010).

b. Setting Up Farmer Organizations

The creation of farmer organizations allows small farmers to be more competitive, achieve economies of scale, reduce transaction costs, enhance their bargaining power, improve their market information, access technology, manage common pool of resources and reduce certification costs (Gonzalez and Nigh, 2005; Vermeulen et al., 2008; Devaux et al., 2009; Magnus and Steenhuijsen, 2010; Markelova and Mwangi, 2010). Farmer organizations can also help to shortcut the supply chain and have a central role in enhancing smallholder and private sector cooperation. The private sector, at the same time, can reduce their transaction costs through a single point of contact, the farmer organization; instead of having multiple dispersed producers. In addition, farmer organizations can also work as a chain facilitator to spread information and assist with technical and financial advice and services (Magnus and Steenhuijsen, 20I0).

Farmer organizations can also offer different functions and services such as marketing, provision of extension services, credit and insurance services, capacity development, input supply, market information, processing, policy analysis, advocacy and campaigning (Vermeulen et al., 2008).

\section{c. Contract Farming}

Small farmers can also be contracted directly by a company. Companies then hold the sustainability certificates and take all the risks, as well as part of the profits. Generally companies buy sustainable products from farmers at a discounted premium price as farmers do not need to incur certification costs. To organize farmers and gather their products, companies have to invest in them (capabilities, access to inputs, knowledge, etc.) and build strong trust relationships (Elzakker and Eyhorn, 2010).

\section{d. Contractual Arrangements}

Contractual arrangements can help to reduce risk and farmers' vulnerabilities (Proctor and Digal, 2008). With contracts, the terms of trade allow farmers to set volume forecasts and quality requirements, predict prices and determine what kind of support can be expected.

Contracts with buyers can have positive outcomes for the farmers in terms of reduced price risks and improved access to market information. They can also improve the access to financial inputs. However, contracts also require compromise with respect to volume, quality and compliance with certification conditions, which can be costly to meet (Magnus and Steenhuijsen, 2010; Riisgaard et al., 2010). Ferrigno et al. (2010) raise the concern that contracts can also be biased against small farmers' interests and do not tackle critical issues, such as risk sharing, indemnity, vague price quotes and vague purchasing compromises (Ferrigno et al., 20I0). Assuring the existence of contractual arrangements while at the same time assuring the fairness of terms is critical.

\section{e. Branding}

Branding allows product differentiation and increased profit and negotiation power along the value chain. Even if branding is rarely associated with small farmers, it can help to better position developing countries' products in local and international markets by adding value and positive image building (Boomsma and Arnoldus, 2008). 


\section{Enhancing Smallholders' Capabilities}

\section{f. Training}

Provision of farmer training enables farmers to improve their production capacity and productivity as well as their abilities to meet the quality standards demanded by international supply chains.

g. Information Systems

Providing smallholders with access to information and communications can help them to make decisions and reach new or more beneficial markets. Market information is crucial for good decision-making (Parikh et al., 2007).

\section{h. Financial Services}

Access to finance has been identified as one of the major issues for small farmer inclusion. There is a growing need to facilitate and adapt financial products for small farmers, such as access to loans, advances for crop finance and crop insurance (Ferrigno et al., 2010).

i. Social Entrepreneurship

Social entrepreneurship aims to improve smallholders' inclusion by providing entrepreneurial opportunities within the supply chain. Several authors identify the relevance of entrepreneurs within farmer organizations who might be able to bridge the gap and coordinate small farmers and market actors (Hall and Matos, 20Io; Magnus and Steenhuijsen, 20I0). Entrepreneurs are more likely to try new technologies and methods and can be triggers for innovation.

\section{The Cotton Industry: How Can Its Sustainability Be Improved?}

Cotton is one of the most widespread and important crops in the world in terms of land area, coming after wheat, rice, corn and soy beans. In 20I0, cotton was grown on 33 million hectares, $2.5 \%$ of the world's arable land. Cotton is produced at commercial scale in 80 countries and it provides livelihoods for Ioo million farmers and 250 million people in associated industries (Ferrigno, 20I0). Ninety per cent of the production is performed in developing countries by small producers with less than two hectares of land (Better Cotton Initiative, 20I0).

Cotton is a difficult crop to grow as it is sensitive to drought, low temperatures and insects. Additionally, it often needs to be rotated with other crops to ensure soil fertility. As a consequence, cotton cultivation can have negative environmental, social and economic impacts, which can threaten farm sustainability. Inefficient irrigation techniques and cultivation practices together with the improper use of fertilizers can lead to water shortages, water contamination and the reduction of soil fertility. It also threatens biodiversity and human health. Low market prices, high cost of fertilizers, delays on payments and unaffordable interest rates lead small farmers into cycles of debt (Better Cotton Initiative, 20I0; Ferrigno, 20ıо; Initiatief Duurzame Handel, 20I0; Solidaridad, 20II).

\section{Cotton Supply Chain Governance Scheme}

Cotton supply chain actors range from small and marginal farmers, intermediates, traders and ginners, to sophisticated mills, textile processors, brands, exporters, retailers and finally the consumer. Figure I depicts the direct market actors as well as relevant services and supporters involved.

During the evaluation of cotton supply chain governance systems, we also included the rotational and interval crops produced by farmers, as they play a relevant role in sustaining small producers' livelihoods. Furthermore, we also analyzed which enabling services were provided by the different projects, such as training, storage facilities, logistics, insurance and financial services, marketing, technical support and the supply of seeds and inputs. Finally, to include the complete stakeholder supply chain network, external support organizations were also mapped. 

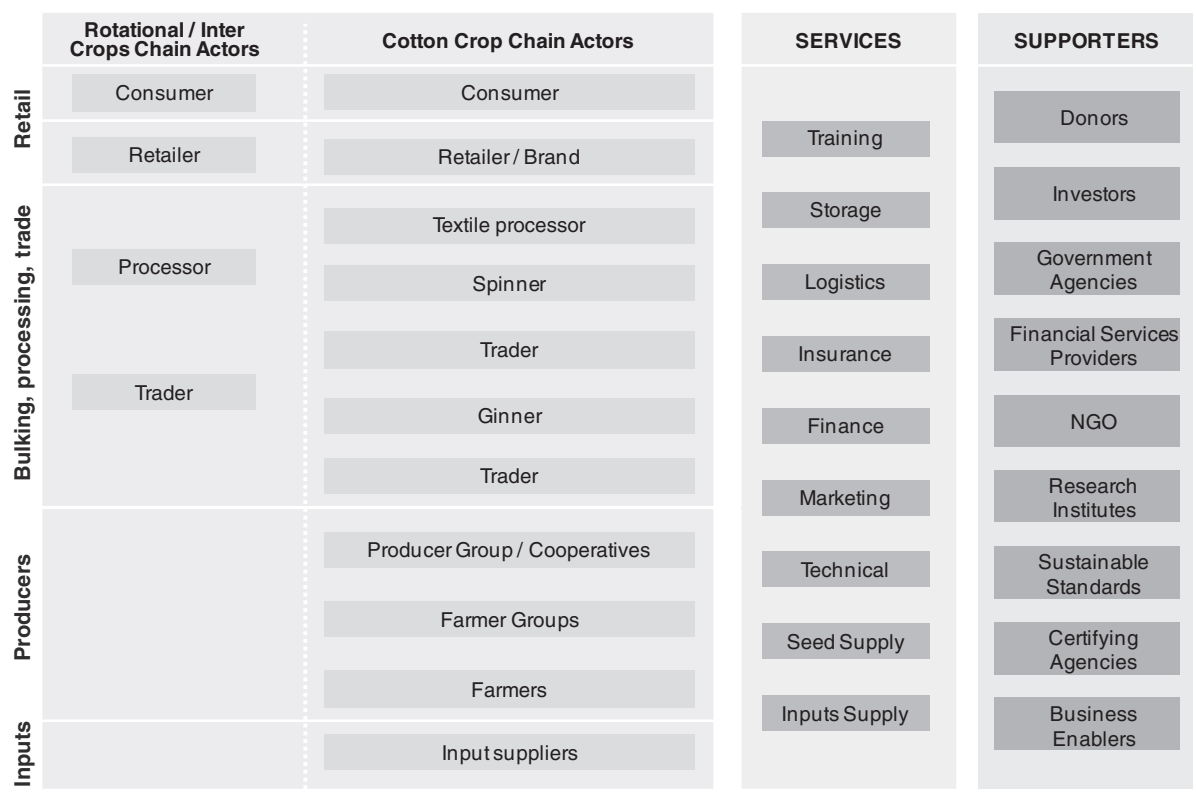

Figure 1. Cotton supply chain governance map based on (Elzakker and Eyhorn, 2010; Ferrigno et al., 2010)

\section{Indian Cotton Particularities}

Over two-thirds of the Indian population are directly dependent for their livelihoods on agriculture. More than $80 \%$ of those are small and marginal landholders with an average of I.4 hectares of land (Parikh et al., 2007; Tirado, 20I0). In addition, $65 \%$ of Indian farmers have rain-fed farms without any additional irrigation facilities (Tirado, 2010).

In India, cotton represents $30 \%$ of the agricultural gross domestic product (Sadashivappa 2009). India is the second cotton producing and consuming country as well as the second largest cotton exporter in the world. The cotton sector represents almost $20 \%$ of all Indian exports and represents the livelihood of 60 million people, including 4.5 million farmers (Prasad et al., 2010).

India has the largest area under cotton cultivation worldwide, in the last decade, because of low field productivity, different government schemes and programmes have been introduced with the aim of intensifying cotton production. In an effort to increase Indian cotton production yields and quality, genetically modified cotton was commercially introduced in India in 2002 with the support and promotion of the Indian government (Schaub, 20I0). With an incredibly high rate of adoption, in $2009 / 2010$ up to $85-90 \%$ of the cotton cultivated area in India was from genetically modified cottonseeds (Cotlook, 20I0).

The expected benefits of adopting genetically modified cottonseeds are better yields and higher cotton fibre quality together with the reduction of pesticide usage (Kooistra and Termorshuizen, 2006). However, actual results have been controversial, ranging from excellent results and reported increases in yields to absolute failure in implementation for small farmers. Medium and larger farmers with access to financial capital and good agricultural inputs (irrigation, pesticides, fertilizers, etc.) seem to achieve the better yields and quality (Sadashivappa, 2009; Schaub, 20I0). However, some small farmers, who cannot afford to invest in irrigation mechanisms and costly agricultural inputs, seem to face difficulties in achieving the better yields and paying back the credits asked (Shiva and Jalees, 2006; Tirado, 2010).

\section{Initiatives for a More Sustainable and Inclusive Cotton Supply Chain}

As a response to the economic, environmental and social challenges of the cotton supply chain together with the specific challenges faced by small farmers, different standards and initiatives have emerged to improve its 
sustainability outputs. The aim of this section is to discuss different international and Indian sustainable cotton standards and present additional sustainable cotton initiatives present in India.

Private Sustainable Cotton Standards

During the last decade different sustainable cotton standards have emerged. These include certification initiatives such as Fairtrade, Organic and Shop for Change, traceability initiatives, such as Better Cotton Initiative and initiatives simply promoting better training and production practices, such as different forms of pest and crop management.

The different private standards have different focal points and verification systems but do not differ extensively in terms of the aspects of sustainability addressed, or the sharing of implementation mechanisms. However, the multiplicity of standards can lead to confusion among brands, consumers and farmers. Table I presents a comprehensive summary of the different cotton standards analyzed, including principles, price mechanisms, regulations and worldwide statistical data; including cotton area, cotton production and the number of farmers.

Each of the different sustainable standards has their own primary goals but shares similar ambitions and objectives in the long term. Fairtrade standards and Shop for Change, emphasize social aspects, the Organic standard focuses on environmental aspects and Better Cotton Initiative aims for productivity. Nevertheless, all of them incorporate environmental, social and economic aspects to some degree.

The standards differ on their pricing schemes. Fairtrade International is the only standard which guarantees a minimum price for the farmers and provides a social premium, whereas Shop for Change assures a capacity building premium. Organic farmers receive a price premium over conventional prices. Finally, Better Cotton Initiative pays conventional market prices and does not charge any royalties.

The standards also differ in the way that they are regulated. Organic certification is regulated by national standards, whereas Fairtrade, Shop for Change and Better Cotton Initiative are regulated by single private organizations. In addition, all end products for each of the standards, with the exception of Better Cotton Initiative, are labelled as such. Another difference among the standards is their traceability. Fairtrade and Organic standards demand separate and certified supply chains, including farmers, ginners, spinners and textile manufacturers. Better Cotton Initiative is tracked and verified until the ginner level and allows brands to use their own supply chain networks and to mix different percentages of Better Cotton within their final products.

Starting dates of the different sustainable standards as well as geographical areas of focus are also different. Organic was the pioneer cotton standard. It started in the I990s with global focus and targeting international markets. International Fairtrade cotton certification started in 2004 focusing on developing countries as producer regions and targeting international markets. Better Cotton Initiative, with starting pilot implementations on 20IO/20II, targets international markets and does not restrict producer countries. Finally, Shop for Change, which started in 2009, targets Indian producers and domestic markets.

Standards also face common challenges. Farmers are required to learn new crop management techniques, put in place verification or traceability systems and in most cases, demand for their sustainable cotton is not guaranteed. In addition, each one of the standards requires an initial investment in small farmers' capacity building and extension services.

Other Sustainable Initiatives for the Indian Cotton Market

Different supportive initiatives have also emerged during the last few years to improve the sustainability of the cotton supply chain. The initiatives identified are diverse in nature and cover a range of activities. These include bringing together farmers with brands and retailers (Textile Exchange), providing consultancy services to help brands and retailers establish sustainable cotton corporate strategies (Textile Exchange and Cotton Connect), helping existing producer companies (Procotton), mapping retailers and brands supply chain networks (Cotton Connect), defining best agricultural practices for cotton farmers (World Wide Fund for Nature, Textile Exchange), and creating online expert discussion platforms (Global Organic Cotton Community platform). The actors setting up these initiatives are mainly NGOs (Textile Exchange, ProCotton, World Wide Fund for Nature, Global Organic Cotton Community platform) and market-based organizations (Cotton Connect). 


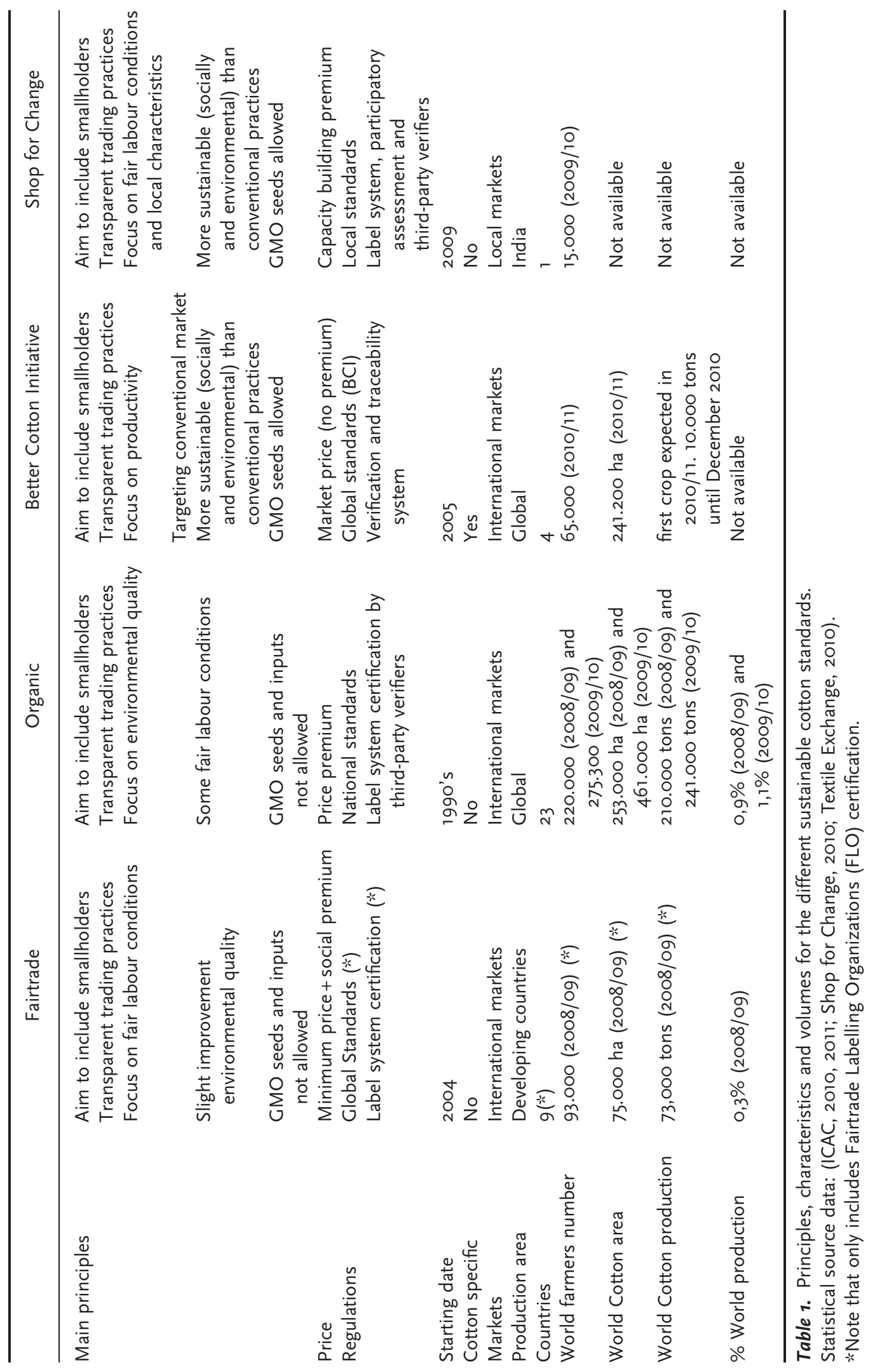




\section{Indian Case Studies of Smallholder Engagement initiatives}

\section{Case studies overview}

The nine selected case studies cover both NGO-based and company-based initiatives and the different cotton standards. In addition, they also encompass farmers of different size whose projects have reached different levels of maturity.

Development-NGO-based Case Studies

\section{Chetna Organic}

Chetna Organic is an Indian farmer support organization that works towards sustainable agriculture and ethical trade. Its main objective is to improve livelihood conditions and to empower small farmers in India. The project was initiated in 2004, has I25 employees and serves 8300 small farmers in Maharastra, Andrha Pradesh and Orissa states. All Chetna products are Organic and Fairtrade certified. In addition, Chetna holds the national fairtrade label Shop for Change and works with Non Pest Management certification. Chetna is directly linked with European fashion buyers of Organic and Fairtrade cotton such as JackPot and Imps\&Elfs. In addition, it has its own network of ginners, spinners and manufacturers such as Sri Saravana, Supper Spinning Mills and Rajlakshmi, to provide final products to its customers.

\section{Zameen}

Zameen Organic is a farmer-owned business organization focused on fairtrade, organic and no pesticide cotton marketing and value addition activities. Zameen Organic works with marginalized cotton farming communities in India and improves their livelihoods by increasing agricultural efficiency, lowering input costs and providing certification. The project started in 2006 and now works with 3800 farmers in Maharastra and Andhra Pradesh states. Zameen products are Organic and Fairtrade certified. In addition, they also use the local Non Pest Management certification, which helps Zameen to create domestic added-value markets for the organic conversion periods. Zameen works with their market links with Alok Industries and others brands to introduce their product into their supply chain structures.

\section{Oxfam}

In 2003, Oxfam, an international humanitarian campaign and development organization, started the 'Cotton Textile Supply Chain Programme' with the objective to improve the livelihoods and alleviate poverty of small cotton farmers, weavers and garments workers. The cotton farmers' project has helped small farmers by introducing organic farming practices and certification schemes and providing market access through collective marketing of their products. The project currently works with I2,000 cotton farmers in 36 villages in Andhra Pradesh. Cotton crops are partially marketed directly through the partnership's relationship with Alok Industries. Alok uses their own supply chain structure and finally sells Oxfam cotton to different brands such as Monsoon. The rest of the cotton is sold as conventional cotton at the Cotton Corporation of India auction cooperatives.

\section{TraidCraft}

TraidCraft is a United Kingdom development non-profit organization. In 2009 it began operating a 3-year project with the goal of improving the livelihood conditions of 300 cotton farmers in Karnataka state. Due to the short 
project period, it was decided to empower farmers and increase their market access via Fairtrade certification. In spite of the low number of farmers involved in the project, market access is assured by the business partnership with Agrocel, one of the largest producers and direct suppliers of organic, fairtrade and other specialty cottons in India. Agrocel has promised to buy the cotton produced by TraidCraft farmers and to market it within its own supply chain structure and network. Final buyers from Agrocel are international brands such as Gossypium.

\section{ACF Nadikudi}

Ambuja Cement Foundation (ACF) is an NGO founded as part of the Corporate Social Responsibility programme of Ambuja Cement Corporation. ACF works with rural communities in the areas surroundings Ambuja manufacturing sites. In 2009, ACF joined the Better Cotton Initiative project in several of their regional offices in India. ACF had previous experience helping farmers to improve their agricultural practices. In Nadikudi, Andrha Pradesh, 738 farmers started to work within Better Cotton Initiative certification. During this first pilot year, ACF Better Cotton Initiative project has not been able to sell the cotton produced as Better Cotton but it had already identified one local ginner and was working towards creating market links and demand for the next season.

Company-based Case Studies

\section{Supper Spinning Mills}

Supper Spinning Mills is a vertical integrated spinner manufacturer. Established in I962, Supper Spinning Mills has implemented different programmes to support cotton farmers, including conventional cotton farming, organic cotton and Better Cotton Initiative in Tamil Nadul state. The Better Cotton Initiative pilot project, the focus of our study, started in 2009 and has involved 4050 farmers. During the first harvest season, cotton was not able to be marketed as Better Cotton Initiative and it was sold in conventional markets. However, reduction of agricultural inputs, especially chemical products, has enabled farmers to increase their profits while maintaining the yields.

\section{Arvind Mills}

Arvind is a large vertical integrated fabric and textile/garment manufacturer based in India. Arvind started its operations in I93I and it currently supplies large international and domestic garment brands. Arvind started a backwards integration programme with farmers in Maharastra state promoting organic farming and most recently also the Better Cotton Initiative. Arvind's contract farming projects involve 3000 organic small farmers and I200 Better Cotton Initiative small farmers. Arvind offers contractual farming arrangements to its farmers. Arvind commits to buying Organic and Better Cotton from farmers at market price according to its quality (staple length). It also facilitates capacity building for farmers and covers certification costs. Eighty per cent of Arvind's clients are international brands such as C\&A, H\&M, Wal-Mart and Patagonia.

\section{Pratibha Syntex}

Pratibha Syntex started as a textile manufacturer in I996 becoming one of the first vertically integrated Indian suppliers of yarns, fabrics and garments. Pratibha entered the organic market with the Vasudha organic farmers' project in I999, despite the fact that there was not a specific demand for Organic cotton at the time. Progressively, 
the company joined other sustainable cotton standards such as Fairtrade. Pratibha works with 23,000 organic farmers in 26 different villages in Madya Pradesh state, of which 3825 are also Fairtrade certified. Pratibha commits to purchasing Organic and Fairtrade cotton from the farmers if quality is maintained and certification is successfully accomplished. It also offers technical assistance and bears certification costs. Approximately $25 \%$ of Pratibha production follows Organic or Fairtrade standards. Currently, the main international brands sourcing its organic garments are Decathlon, Nike, Roots and Lululemon.

\section{BioRe India}

Remei AG, an ethical Swiss textile company started the BioRe organic project in India in I99I. One special characteristic of Remei AG is that its whole production, from cotton bales, yarn, fabrics and clothing, is exclusively made using organic cotton in their own facilities. In parallel, BioRe Foundation was established in Switzerland in I997 as a social organization with the aim of empowering organic farmers and their communities. It seeks to accomplish these goals by facilitating education, promoting infrastructure and addressing local needs. In 2010 BioRe India was working with 6455 farmers. BioRe products are Organic and socially certified. BioRe has been a pioneer in establishing social and premium standards because when they started Fairtrade standards had not yet been developed. BioRe offers contractual farming arrangements, including 5-year commitments, product purchase guarantees and a BioRe price premium. The main buyers of Remei AG are COOP, a Switzerland supermarket chain, and others supermarkets and fashion outlets in France, Germany and other western European countries.

To summarize the case studies, Table 2 presents an overview of the different case studies, indicating their staring dates, the number of farmers involved, which sustainable cotton standards are being used, which inclusion mechanisms are in place and which additional services are provided.

\section{Case Studies Comparison and Analysis}

The nine case studies can be roughly grouped into two approaches: development-NGO-based and company-based approaches. In the case of NGO projects the motivation stems from a desire to improve farmers' livelihoods by means of increasing their agricultural efficiency, lowering input costs, facilitating market access through collective marketing and helping farmers to become certified. In some of the projects, such as Chetna Organic, strong community development and institution building are also encouraged as a crucial component of their developmental approach. In the case of companies-based projects, the drive to encourage sustainable cotton projects derives from a strong and strategic commitment to sustainability, improvement of cotton farmer conditions, and a desire to increase traceability, transparency and integrity of their cotton supply chains.

\section{Sustainable Cotton Standards}

The case studies cover different sets of sustainable cotton standards, including Organic, Fairtrade, Shop for Change, Better Cotton Initiative, Non Pest Management and even corporate standards. The rationale for the selection of each project varied.

Chetna Organic and Zameen have a single common message for their farmers as to which practices and requirements need to be fulfilled. The standards they use combine a mix of international and national labels to increase the sustainable market share for their products. After trying to market the maximum of their production under international Organic and Fairtrade labels simultaneously, which enables the better returns for their farmers (Organic and Fairtrade premiums), the remaining product is sold as only Organic where more market demand exists. Cotton production still in the process of organic conversion is sold under the Fairtrade label. Joining Shop for Change certification, Chetna and Zameen aim to improve Fairtrade market access by expanding to local markets. Non-cotton crops are also marketed as Organic or as Non Pest Management products in domestic markets. TraidCraft and Oxfam projects, with Fairtrade and Organic certification respectively, are also considering adopting Organic and Fairtrade certification for their farmers in the future. 


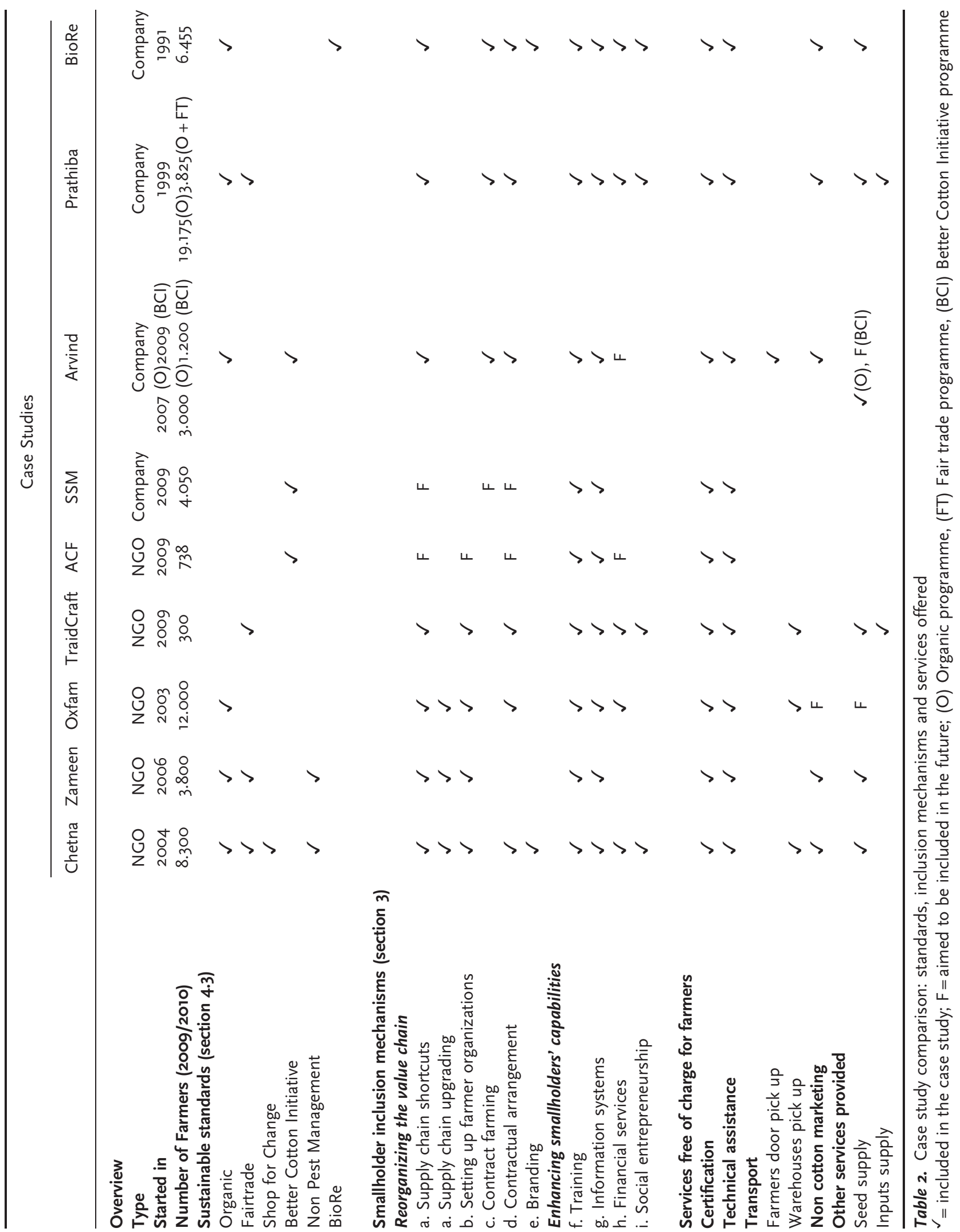


The four company-based projects mainly work with Organic cotton standards as they also face more difficulties in selling products as Fairtrade due to the lower market demand. For these company-based projects, the cotton standard selection, as well as the certification agencies, are mainly market driven.

Inclusion Mechanisms

In all nine case studies, the firms and the NGOs work on shortening the value chain to benefit small producers and companies as transaction costs are reduced. Small farmers have upgraded their positions in most of the NGO projects, where farmer production companies are being established and farmers' products are marketed (Chetna, Zameen, Oxfam and TraidCraft). In addition, in the Chetna project farmers have started processing their non-cotton crops and will soon be packaging them for direct sale to local retailers under their own brand. Zameen is marketing raw non-cotton crops and the Oxfam project is also aiming to do so in the near future.

All the farmers' organizations established by NGOs share a similar structural approach. Starting with capacity building, NGOs help farmers to become organized in self-help groups and cooperatives, emphasizing the importance of building strong institutions, introducing good agricultural practices, and providing extension services and certification. In parallel, production companies are set-up with the aim of increasing farmers' marketing skills and allowing them to directly market their products. During the start-up years, this twofold approach is generally maintained. The NGOs' support and funding allow time for producer capacity building and for the strengthening of institutions until the producer company can become profitable and self-sustaining.

Contract farming models are based on contractual arrangements between the farmers and the manufacturing company or other supply chain partners. Companies commit to purchasing the farmers' cotton at a certain price if farmers fulfil certification requirements and cotton quality. Companies take full responsibility for certification costs, training and agricultural extension services, which are offered free of cost to the farmers. In addition, some companies such as BioRe, include two parallel organizations. BioRe India, the private limited company, takes care of the cotton purchasing, and BioRe Association, a non-profit organization, addresses social issues among farmers and their communities.

All the different projects have helped farmers to improve their access to information. This is facilitated either by the project field teams or by improved information linkages among farmers working as a group.

Social entrepreneurial activities have been performed using the social Fairtrade premiums or via NGO or foundation set-ups.

All the projects focus on technical and agricultural extension, including organic or integrated pest management practices. The collective aim of all the projects is to help farmers to reduce agricultural inputs and to improve their productivity.

Access to finance has also arisen as a key component of the programmes. Even though providing finance to farmers is not a main focus of the projects, some of them try to facilitate financial access for farmers. Financial access is facilitated in the form of loans and savings groups (present in Chetna and TraidCraft, and also planned for the near future for Arvind and ACF Nadikudi), credits via their cooperatives (Oxfam) or via associations (BioRe Association), or by advancing seeds and other inputs without interests (Pratibha).

All the case study organizations provide free certification and technical assistance to the farmers. In the case of the NGO projects, certification costs are initially covered by the development-NGO and aimed to be progressively transferred to the cooperatives and/or farmers' producer companies. In the case of company-based projects, corporations bear certification and technical assistance costs. Some of the case studies additionally provide logistic facilities free of cost.

\section{Experiences: What Has Been Achieved?}

Before the different interventions, farmers faced similar situations, with some variations across the geographical areas. Small cotton farmers lacked access to capital and finance and were generally facing reduced cotton yields, increased pest attacks, and increasing usage of chemical pesticides. Furthermore, farmers faced an increase of agricultural input costs, volatile prices for cotton and payment risks. In some of the cases, as in Langingar district in Orissa, the final price obtained for the cotton was not enough to cover the production costs and farmers had to abandon the cotton crop. Market access was mainly monopolized and exploited by local middlemen, who controlled 
the price at which cotton was bought from the farmers. These same middlemen generally sold them the chemical agricultural inputs. Market access improved with the introduction of governmental auction cooperatives, ruled for example by the Cotton Corporation of India. However, the maturity and organization of the cotton market still differs among different states. In addition, farmers could not always sell their cotton to the government cooperatives because of the time needed and logistical constraints, and because middlemen were still playing a significant role in most of the cases.

The different experiences and results for each of the case studies, including economic, environmental and social impacts, have been summarized in Table 3.

Regarding the economic impact, all the projects with market access for their sustainable certified or verified cotton have seen better payment conditions and have increased the transparency of their operations. Companybased projects have usually achieved better market access than NGO-based projects, because they can use their own supply chain and market structures. Some NGOs such as Chetna Organic and TraidCraft have also achieved good market access. TraidCraft via its partnership with Agrocel, one of the largest producers and direct suppliers of Organic, Fairtrade and other specialty cottons in India, can market all their cotton production. Chetna Organic is directly linked to European fashion buyers and has its own local network of ginners, spinners and manufacturers. However, other projects such as Zameen and Oxfam could only market part of their cotton production as sustainable cotton in 20I0-20II, whereas the rest was sold in conventional markets.

All the projects could also reduce farmers' production costs. Directly related to the reduction or full banning of pesticides, all projects had a positive impact on the final profits of farmers. At the same time (with exception of ACF Nadikudi due to severe flooding) all projects maintained or even improved cotton yields.

All the case studies showed improvements in their environmental impacts. Chemical pesticide usage has been stopped (organic projects) or reduced by up to 40-50\%. In addition, water management and soil fertility have been improved.

Regarding the social impacts, the most relevant impacts were in health and education. Discontinuing use of chemical products in the organic projects, and the reduction and better handling of chemical products in others, have contributed to improving the health of farmers and their families. In addition, some projects have performed

\begin{tabular}{|c|c|c|c|c|c|c|c|c|c|}
\hline & \multicolumn{9}{|c|}{ Case Studies } \\
\hline & Chetna & Zameen & Oxfam & TraidCraft & ACF & SSM & Arvind & Prathiba & BioRe \\
\hline \multicolumn{10}{|l|}{ Initiative results } \\
\hline \multicolumn{10}{|l|}{ Economic impact } \\
\hline Market access & $\checkmark \checkmark$ & $\checkmark$ & $\checkmark$ & $\checkmark$ & & & $\checkmark \checkmark$ & $\checkmark \checkmark$ & $\checkmark \checkmark$ \\
\hline Production cost reduction & $\checkmark \checkmark$ & $\checkmark \checkmark$ & $\checkmark \checkmark$ & $\checkmark \checkmark$ & $\checkmark$ & $\checkmark$ & $\checkmark \checkmark(\mathrm{O}), \sqrt{ }(\mathrm{BCl})$ & $\checkmark \checkmark$ & $\checkmark \checkmark$ \\
\hline Yield production & $=/ \mathrm{S}$ & $=$ & $=/ \mathrm{V}$ & $=$ & & $=/ \mathrm{S}$ & $=/ \mathcal{V}(\mathrm{O}), \mathcal{V}(\mathrm{BCl})$ & $=/ \mathrm{S}$ & $=/ \mathrm{J}$ \\
\hline Better payments & $\checkmark$ & $\checkmark$ & $\checkmark$ & $\checkmark$ & & & 2 & 2 & $\checkmark$ \\
\hline Farmer shares & $\checkmark$ & $\checkmark$ & $\checkmark$ & & & & & & $\mathrm{F}$ \\
\hline \multicolumn{10}{|l|}{ Environmental impact } \\
\hline Pesticides reduction & $\checkmark \checkmark$ & $\checkmark \checkmark$ & $\checkmark \checkmark$ & $\checkmark$ & $\checkmark$ & $\checkmark$ & $\checkmark \checkmark(\mathrm{O}), \sqrt{ }(\mathrm{BCl})$ & $\checkmark \checkmark$ & $\checkmark \checkmark$ \\
\hline Water management & $\checkmark$ & $\checkmark$ & $\checkmark$ & $\checkmark$ & $\checkmark$ & $\checkmark$ & $\checkmark$ & $\checkmark$ & $\checkmark$ \\
\hline Soil fertility & $\checkmark$ & $\checkmark$ & $\checkmark$ & $\checkmark$ & $\checkmark$ & $\checkmark$ & $\checkmark$ & $\checkmark$ & $\checkmark$ \\
\hline \multicolumn{10}{|l|}{ Social impact } \\
\hline Health & $\checkmark \checkmark$ & $\checkmark \checkmark$ & $\checkmark$ & $\checkmark \checkmark$ & $\checkmark$ & $\checkmark$ & $\checkmark$ & $\checkmark \checkmark$ & $\checkmark \checkmark$ \\
\hline Education & $\checkmark \checkmark$ & $\checkmark$ & $\checkmark$ & $\checkmark$ & $\checkmark$ & $\checkmark$ & $\checkmark$ & $\checkmark \checkmark$ & $\checkmark \checkmark$ \\
\hline
\end{tabular}

Table 3. Case study results comparison

$\checkmark \checkmark$, very positive impact; $\checkmark$, positive impact; $F$, aimed to be included in the future.

(O), Organic programme, (FT) Fairtrade programme, (BCI) Better Cotton Initiative programme

Yield production: $=$, yield maintenance; $=/ \checkmark$, yield maintenance and sometimes improved; $\checkmark$, yield improved. 
special health programmes funded by Fairtrade social premiums or foundation donations. These projects provide farmers with annual health checks or have created mobile hospital centres. Education has been improved by all the projects, with an emphasis on fostering awareness of the importance of school attendance. These projects do not allow child labour, or only allow the children to help their families during holiday periods. Some projects have also used Fairtrade social premiums or foundation donations to build schools.

Benefits of Sustainable Cotton Standards

Organic farmers have achieved better payment practices and organic premiums. Premiums received by organic farmers depend upon the projects; BioRe offers a premium of $15 \%$ up to market price, Chetna offers IO-I5\% price premium and Pratibha offers up to 5-10\% premium. Other projects, such as Zameen offer variable premiums according to which final price the final buyer has paid for the organic cotton. In other cases, such as Arvind, no organic price premium is paid but additional logistic services are offered in return. Organic farmers have also reduced agricultural input costs (no usage of any chemical input) even if sometimes organic practices require more labour input. They have also been able to maintain or even increase the yields after the 2- to 3-year conversion period.

Fairtrade farmers also have better payment practices. The minimum price guarantee reduces farmers' vulnerability to market prices fluctuations and the 'social building premium' enables investments at the community and farmer levels. 'Producers Executive Body' creation assures farmer organization and institution building. BioRe social standard goes beyond Fairtrade minimum price and assures a 15\% price premium over the previous 5 years' average cotton price.

Better Cotton Initiative farmers have been able to reduce the use of chemical products by up to $40-50 \%$ while maintaining or increasing cotton yields. In addition, the Better Cotton Initiative has increased the farmers' awareness of the importance of children's education.

\section{Benefits of Inclusion Mechanisms}

Farmer organizations enable farmers to build institutions and empower the creation of farmer-owned companies. In contract farming, market access is easily assured as cotton production becomes directly integrated in the company supply chain network.

In all of the cases, extension support is needed and it has been identified as a key aspect for the successful implementation of the projects. On average, the extension rate was around one extension field staff per 65 to 100 farmers.

\section{Challenges to Overcome}

Challenges of Sustainable Cotton Standards

All the case studies agree that certification is costly and laborious. Extension service field staff invest an average of almost $50 \%$ of their time in certification-related activities.

Seed supply is one main challenge for Organic certification, as organic seeds are rarely available in local Indian stores. Most of the organic projects visited, both development-NGO and company-based initiatives, are currently investing in producing their own seeds (Chetna Organic, Pratibha and BioRe) or are planning to do so (Zameen and Oxfam). Other challenges include certification integrity and a reduction in the Organic premium price because of high cotton market prices. In addition, the 3-year conversion period to change conventional farms to organic production discourages many conventional farmers who are already using chemical inputs. Contamination with genetically modified organisms (GMO) is another risk to be faced in organic farming, which requires additional investments and produces uncertainty, as the final product cannot be easily assured to be free of GMO. Even after taking precautions (analyzing the seeds, assuring organic practices and fences, organic harvesting kits, etc.) contamination can still happen.

Regarding organic market access, some of the NGO organizations are having difficulties selling all their cotton as organic; therefore, part of the organic production is sold in conventional markets. The company-based initiatives are not facing major difficulties to market their organic cotton and sometimes they need to purchase organic cotton outside their programmes. 
As international Fairtrade standards do not allow the use of genetically modified seeds, Fairtrade certification also faces difficulties in finding non-GMO seeds in local markets and shares the possible contamination risks. Fairtrade cases also have difficulty accessing markets, both for NGO and company-based projects.

During the first year of implementation of the Better Cotton Initiative, only a small part of the cotton produced under the standard has been able to be sold as Better Cotton. None of the NGO partners but only Arvind and Agrocel have been able to sell small volumes of Better Cotton to final buyers. The primary reasons have been the lack of confirmed orders for Better Cotton and the need to invest in the ginners so they can adopt their processes to track Better Cotton separately from conventional cotton. Better Cotton Initiative is currently working on improving supply chain management and assuring market connections for the next harvest season. Another challenge that Better Cotton Initiative is facing is to become self-sustaining without premiums. Even if the Better Cotton Initiative approach is more flexible and enables optimization and reduction of certifications costs (because there is no need for separate tracking after ginning level and it allows different percentages of Better Cotton to be used on the garment), some structural costs, such as farmer training and extension services, verification and additional ginning costs are still present. In addition, being a cotton seed neutral standard, the Better Cotton Initiative needs to elaborate a good strategy in India to assure proper seed selection for its farmers.

Challenges of Inclusion Mechanisms

The main challenges facing farmer organizations are the following. First, NGO structure is dependent on the funds available and has to successfully create strong, independent, transparent and long-lasting institutional structures. Second, producer companies have to become self-sustaining, be able to cover capacity building and certification costs in the long run and create long-term market linkage relationships. In the start-up phase, the main challenge shared by all the producer companies is related with the difficulty in acquiring the working capital required to pay the farmers and sell the cotton. Some projects are dealing with this difficulty by creating revolving funds for the first few years, by asking for pre-financing from the buyers or by receiving payment facilities from their own farmer cooperatives.

In contract farming set ups, with investment of the companies themselves and usage of their own supply chain, farmers' organizational capacities and institutional building are usually weaker.

\section{Cotton market prices}

High fluctuations in cotton prices make the long-term commitment of buyers difficult, especially for the NGO-based projects. This instability, together with the high increase of cotton prices, can negatively affect brand interest in longterm investment in sustainable cotton.

\section{Demand and Supply Balance}

To assure sustainable cotton sourcing, it is necessary to balance buyers' orders and cotton harvests. Farmers usually face urgent cash requirements during the harvest period. If sustainable cotton purchasing orders are delayed, farmers are forced to sell part of their cotton on the conventional market.

In addition, long-term planning of sustainable cotton demand will also help farmers and projects to forecast the specific sustainable inputs required (e.g. organic seeds and inputs) for the next harvesting seasons and to secure supply volumes.

\section{Conventional Market Competition and Genetically Modified Cotton}

Sustainable agricultural practices need to address the GMO market competition. Strong and aggressive marketing for genetically modified seeds is present in India. Seed supply companies and local traders are pushing this market because it is more profitable than conventional seeds. Genetically modified seeds are sold at two to three times the price of conventional seeds. Furthermore, farmers cannot save genetically modified seeds for the next season and have to buy the seeds every year.

The various sustainable cotton standards adopt different perspectives. Organic and International Fairtrade organizations do not accept any GMO seed or GMO agricultural inputs, whereas Better Cotton Initiative and Shop for Change do allow it. In addition, uncertainties in the future impacts and long-term risk for the environment, health and contamination of other non-genetically modified crops are also present. 


\section{Reflection}

All the case studies reflect a relevant improvement of the small farmers' situations after the implementation of the different projects and certification schemes. Farmers have improved their profits by receiving better payment conditions, reducing their production costs and maintaining or even increasing their yields. In addition, positive environmental impacts are achieved while reducing or even stopping the use of chemical pesticides and fertilizers. The final results achieved depend partially on the standards. Implementation mechanisms are a relevant aspect that would determine together with the standards the specific benefits for the farmers and the long-term success of the projects.

One of the key components demonstrated by the cases is the need to integrate supply chain orientation with developmental approaches. Strong market linkages need to be created to assure market access for the products. Company-based projects have easier market access because they have their own supply chains and market connections. Development-NGO projects generally need an extra effort to create market links and are already working on professionalizing their structures by setting up farmers' companies. Developmental approaches implemented mainly by NGO projects are relevant to assure small farmer livelihoods and to take into consideration local characteristics and needs.

What may be seen as a gap among company-based and development-NGO approaches can be instead transformed into a win-win situation by joining the best practices and expertise held by firms and NGOs, which respectively have expertise in market linkages and supply chain efficiency, and developmental approaches at community levels. Trust and long-standing relationships with farmers and companies is central to coping with market instabilities. Investment is needed in farmers to create professionalized and sustainable organizations and secure, in return, loyalty and betterquality products. In this arena, the different support initiatives will play a relevant role as facilitators and enhancers.

The case studies also show how the different sustainability standards (Organic, Fairtrade, Shop for Change, Better Cotton and Non Pest Management) can help to create market access, facilitate organic transition periods and gather flexibility to work with either local or international markets. Proliferation of private sustainability standards can be seen as a positive development as long as they work together and increase volumes of sustainablecotton. However, the multiplicity of different standards can also lead to confusion for brands, consumers and farmers. It is therefore necessary to establish the similarities and differences among them so that they work in a complimentary way and avoid competition. The primary motivation for farmers joining the different sustainability projects is economic. All the projects offer increased revenues and economic stability. After economic stability, social and environmental aspects become more relevant. Farmers themselves do not really have an increased range of more sustainable options to choose from. They rarely know any other additional sustainable standards or options besides the one with which they are involved.

Some additional important lessons learned when working with small cotton farmers are the relevance and potential of marketing non-cotton crops as well as adding value to them via processing and branding. In addition, food security of farmers cultivating crash crops is very important and needs to be considered when implementing cotton programmes.

The initial introduction of the programmes to small farmers is challenging. The cases reflected the need to break deep-seated social and economic structures of conventional practices. Farmers are also sceptical of the promised improvements. After some successful pilots with pioneer farmers, and after the use of demonstration plots, farmers become progressively more engaged and willing to join the initiatives.

\section{Conclusions}

The different sustainable standards and inclusion mechanisms discussed in this article can address some of the unintended negative effects of voluntary certification schemes identified in Section I. Crucial for this is to jointly cooperate in identifying and addressing local structures and needs. Recently Porter and Kramer (20II) argued that the time has come for an expanded view of value creation, referring to the growing awareness of employees and citizens and the increased scarcity of resources. In their argument they predict that this will drive unprecedented 
opportunities to create 'shared value'. They see this as a more sophisticated form of capitalism, one imbued with a social purpose: 'but that purpose should arise not out of charity, but out of a deeper understanding of competition and economic value creation" (Porter and Kramer, 20II, p. I7). With this they argue to move beyond charity-driven corporate social responsibility, to what they labelled as 'creating shared value'. With this concept they refer to some of the more collaborative approaches in supply chain governance, which we have described in this article. In their view a shared value perspective focuses on improving growing techniques, and strengthening the local cluster to supporting suppliers and other institutions to increase farmers' efficiency, yields, product quality and sustainability. "This leads to a bigger pie of revenues and profits that benefit both farmers and the companies that buy from them" (Porter and Kramer, 20II, p. 5). In this article we analyzed some of the recent effort to create shared value in practice, with a special focus on barriers for smallholders to get a larger slice of the pie. The opportunities are clearly available, but in practice various not well-connected efforts, partly from the world of development-NGO and partly from business redesigning their value chains, are not easily integrated.

Seen from the perspective of Indian small farmers, sustainable options are still only available to them if capacity building and extension services are provided to them. Sustainable practices require initial investments to create the structures, institutions, capacities, extensions, certification and supply chain tracking. Connecting the two different groups of initiatives and the involvement of more supply chain actors can create a promising future but it is necessary that all the different initiatives, stakeholders, implementation mechanisms and standards join efforts to maximize their positive effects, share best practices and overcome the challenges identified. As an implication of this it would be wise to foster cooperation among development-NGOs and firms that are willing to work towards shared value creation, by jointly creating improved sustainable supply chain systems for small farmers. Their focus would need to be on balancing market chain development and efficiency with developmental approaches at farmer level. Providers of certification systems should need to work on synergies and comparative frameworks among their different sustainability standards, to help buyers, consumers and farmers to be aware of the possibilities and make informed decisions. In addition, competition among standards should be avoided to improve the volume of sustainable production worldwide.

Another aspect that needs more attention is how governments can more actively promote this type of collaboration in the integrated product policies and development cooperation policies (see also Vermeulen and Kok, 20I2). The challenge here is to use the advantages of competition between various certification schemes and support improvement of the quality of private sustainability standards and strengthen two types of inclusion activities as shown in this article.

Appendix A. Preliminary interviews and contacts

\begin{tabular}{|c|c|c|c|c|c|}
\hline & Date & Organization & Contact & & Where \\
\hline 1 & $08 / 12 / 2010$ & ICCO & André Vording & $\begin{array}{l}\text { Policy Advisor Fair } \\
\text { Economic Development }\end{array}$ & Utrecht \\
\hline 2 & $10 / 12 / 2010$ & $\begin{array}{l}\text { Better Cotton } \\
\text { Initiative }\end{array}$ & Deboleena Sengupta & $\begin{array}{l}\text { India Solidaridad } \mathrm{BCl} \\
\text { implementation responsible }\end{array}$ & Skype (Utrecht - Boston) \\
\hline 3 & $15 / 12 / 2010$ & $\begin{array}{l}\text { Freelance \& } \\
\text { People } 4 \text { Earth }\end{array}$ & Ward de Groote & $\begin{array}{l}\text { Sustainable Freelance and } \\
\text { People4Earth CEO advisory }\end{array}$ & Amersfoort \\
\hline 4 & $20 / 12 / 2010$ & $\begin{array}{l}\text { One Planet, } \\
\text { People } 4 \text { Earth }\end{array}$ & $\begin{array}{l}\text { Till Loeper and } \\
\text { Sameer Safaya }\end{array}$ & Researchers & Amersfoort \\
\hline 5 & $05 / 01 / 2011$ & $\begin{array}{l}\text { Initiatief Duurzame } \\
\text { Handel }\end{array}$ & Amanda Stone & Cotton Programme leader & Skype (Barcelona - Utrecht) \\
\hline 6 & $17 / 01 / 2011$ & Wageningen UR & Ted Schrader & $\begin{array}{l}\text { Advisor on farmer empowerment, } \\
\text { rural innovation and } \\
\text { agribusiness development }\end{array}$ & by email \\
\hline 7 & $21 / 01 / 2011$ & ICCO & Marian van Weert & Cotton Programme leader & Call (Barcelona - Utrecht) \\
\hline 8 & $21 / 01 / 2011$ & & Simon Ferrigno & Consultant & Skype (Barcelona - UK) \\
\hline
\end{tabular}




\begin{tabular}{|c|c|c|c|c|c|}
\hline \multirow[b]{2}{*}{9} & \multirow[b]{2}{*}{$22 / 01 / 2011$} & \multicolumn{4}{|l|}{$\begin{array}{l}\text { Cotton Freelance } \\
\text { Consultant }\end{array}$} \\
\hline & & $\begin{array}{l}\text { SNV Netherlands } \\
\text { Development } \\
\text { Organization }\end{array}$ & Joost Nelen & Agriculture leader & by email \\
\hline 10 & $18 / 02 / 2011$ & $\begin{array}{l}\text { Cotton Advisor } \\
\text { / Zameen }\end{array}$ & Gijs Spoor & Consultant & Call (Delhi - Pondicheri) \\
\hline 11 & $21 / 02 / 2011$ & Navdanya & Margaret & Staff member & Delhi \\
\hline 12 & $28 / 02 / 2011$ & Chetna & Arun Ambatipudi & Chetna Executive Director & Call (Delhi - Hyderabad) \\
\hline 13 & $02 / 03 / 2011$ & Solidaridad & Gagan Metha & $\begin{array}{l}\text { Senior Programme Officer } \\
\text { at Solidaridad South and } \\
\text { South East Asia }\end{array}$ & Delhi \\
\hline 14 & $03 / 03 / 2011$ & Cotton Connect & Anita Chester & Cotton Connect South Asia CEO & Delhi \\
\hline 15 & $14 / 03 / 2011$ & WWF-India & Sumit Roy & WWF-India Cotton Project Team & Delhi \\
\hline 16 & $02 / 05 / 2011$ & Shop for Change & Seth Petchers & CEO of Shop for Change & Call Delhi - Mumbai \\
\hline
\end{tabular}

\section{Appendix B. Case studies interviews and contacts}

\section{Case Study \\ Chetna Organic}

\section{Zameen}

Oxfam

TraidCraft

ACF Nadikudi

Super Spinning Mills

Arvind Mills
Interviews, contacts and place

Management Interviews - Chetna Central Offices, Hyderabad Arun Ambatipudi, Executive director

Rama Krishna, Programme director

Ashutosh Deshpande, CEO Chetna Producer Company

Field Visit 1 - Yavatmal, Maharastra.

Hemant Kumar Thakre, Maharstra State Coordinator Jalal Gilani, Chairman of SAGAR Fibers Spinning Unit Annual meeting COAPC

Field Visit 2 - Bhawanipatna, Orissa.

Langigar village and farmers interaction (one farmer)

Golamundi village and farmers interaction (two farmers)

Bhavanipatna village and farmers interaction (three farmers)

Mr. Gao, Orissa State Coordinator

Management Interviews - AOFG Central Offices, Hyderabad

Mr.Stan, Program Manager AOFG

Management Interviews - Oxfam Offices, Hyderabad

Ms.K Vanaja, Project Officer

Management Interviews - TraidCraft Offices, Hyderabad

Ms.Sudha Mullapudi, Program Manager

Management Interviews - ACF Offices, Nadikudi

Rama Raju, ACF-Nadikudi Team Leader

Siva Krishna Babu, ACF-Nadikudi BCI Team member

Field Visit - Interaction with three farmers at ACF Offices

Management Interviews - Super Spinning Mills, Coimbatore

Selvin Lloyd, Sustainable cotton Project Manager

Field Visit - Interaction with three farmers at ACF Offices

R. Palaniappan, $\mathrm{BCl}$ project officer

Farmers Group 1 (eight farmers)

Farmers Group 2 (four farmers)

Farmers Group 3 (seven farmers)

Management Interviews

Mr. Mahesh Ramakrishnan, Head of Agribusiness

Organic Project 


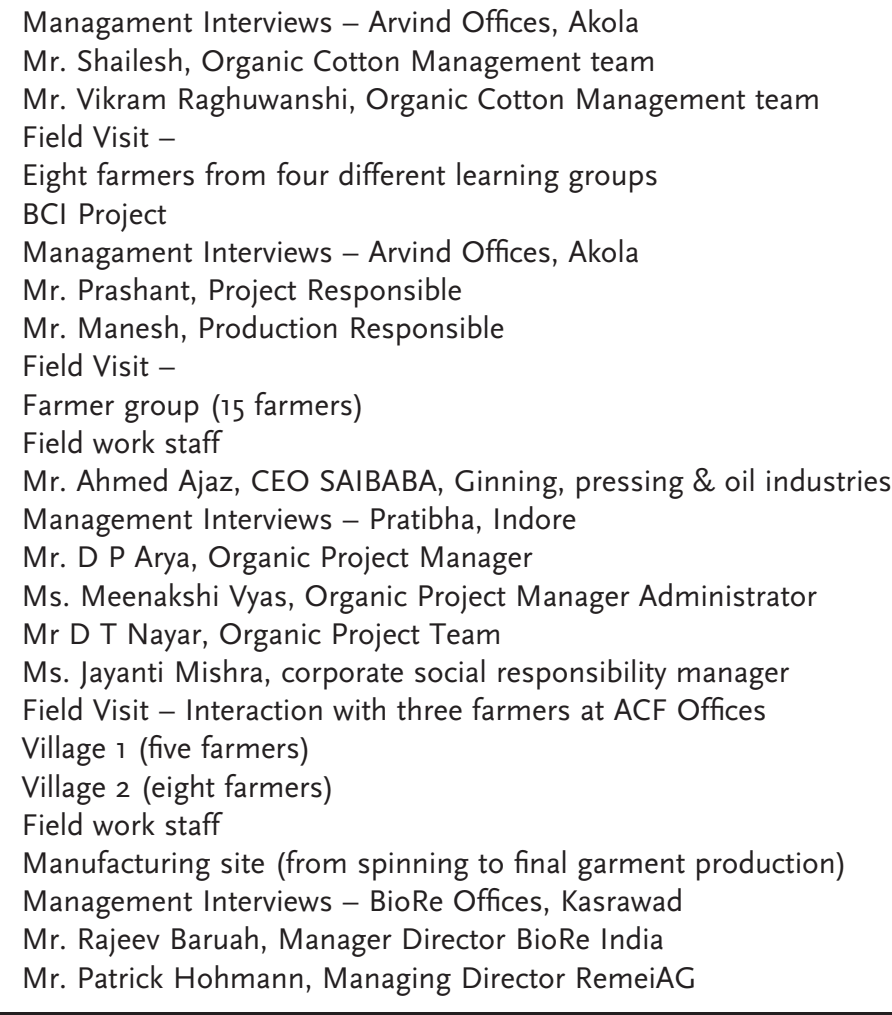

\section{References}

Alberto A. 2009. Living in times of solidarity: Fair trade and the fractured life worlds of guatemalan coffee farmers. Journal of International Development 2I(7): IO3I-IO4I.

Alexander, KS, Millar J, Lipscombe N. 2010. Sustainable development in the uplands of lao PDR Sustainable Development I8(I): 62-70.

Ashley C, Mitchell J. 2008. Doing the right thing approximately not the wrong thing precisely: Challenges of monitoring impacts of pro-poor interventions in tourism value chains. Overseas Development Institute: London.

Bacon C. 2005. Confronting the Coffee Crisis: Can Fair Trade, Organic, and Specialty Coffees Reduce Small-Scale Farmer Vulnerability in Northern Nicaragua? World Development 33(3): 497-5II.

Belton B, Little D, Grady K. 2009. Is responsible aquaculture sustainable aquaculture? WWF and the eco-certification of Tilapia. Society and Natural Resources 22(9): 840-855.

Better Cotton Initiative. 20I0. http://www.bettercotton.org/. [26 November, 20I0].

Beuningen C, Knorringa P. 2009. Inclusive improvement standards and smallholders. Taking stock and moving on. HIVOS http://www.hivos. nl/eng/Hivos-Knowledge-Programme/Publications2/Book-Inclusive-Improvement-Standards-and-Smallholders. [I7 January 20II].

Blowfield M. 2003. Ethical supply chains in the cocoa, coffee and tea industries. Greener Management International 43: I5-24.

Bolwig S, Gibbon P, Jones S. 2009. The Economics of Smallholder Organic Contract Farming in Tropical Africa. World Development 37(6): IO94-IIO4.

Boomsma M, Arnoldus M. 2008. Branding for development. Desk research into the value of branding for development. KIT working papers. KIT Publishers: Amsterdam.

Cotlook. 20IO. http://www.cotlook.com/. [28 January 20II].

Cramer JM. 2008. Organizing corporate social responsibility in international product chains. Journal of Cleaner Production $\mathbf{1 6}(3)$ : 395-400.

Devaux A, Horton D, Velasco C, Thiele G, López G, Bernet T, Reinoso I, Ordinola M. 2009. Collective action for market chain innovation in the Andes. Food Policy 34(I): 3I-38.

Elzakker B, Eyhorn F. 20I0. The Organic Business Guide. Developing sustainable value chains with smallholders. IFOAM: Bonn.

Ferrigno S. 20I0. Cotton sector needs holistic approach. Cotton production trends and sustainability. EcotextileNews December 2010 / January 20II: $28-32$.

Ferrigno S, Lizzaraga A, Tovignan S, Nagarajan P. 20Io. Beyond Organic, Ensuring Responsible Fibre Production and Trade in Organic Cotton A background report into existing practices as a preliminary step towards a Guidance Code on Rights, Responsibilities and Obligations for farmers, traders, promoters, service providers and buyers. Textile Exchange http://textileexchange.org/content/textile-exchange-publications [2I January 20II]. 
Francesconi GN, Heerink N, D’Haese M. 20I0. Evolution and challenges of dairy supply chains: Evidence from supermarkets, industries and consumers in Ethiopia. Food Policy 35(I): 60-68.

Freidberg S. 2003. Cleaning up down South: supermarkets, ethical trade and African horticulture. Social and Cultural Geography 4(I): 27-43.

Gonzalez AA, Nigh R. 2005. Smallholder participation and certification of organic farm products in Mexico. Journal of Rural Studies 2I(4): 449-460.

Hall J, Matos S. 20I0. Incorporating impoverished communities in sustainable supply chains. International Journal of Physical Distribution and Logistics Management 40(I-2): I24-I47.

ICAC. 20Io. Cotton: Review of the World Situation. International Cotton Advisory Committee 63(5). ICAC: Washington DC.

ICAC. 20II. Descriptions of production programs: Organic, Fair Trade, Cotton Made in Africa and the Better Cotton Initiative. International Cotton Advisory Committee SC-N-509(Attachment III). ICAC: Washington DC.

Initiatief Duurzame Handel. 20I0. http://www.duurzamehandel.com/en/cotton. [26 November 20Io].

Ito S. 2004. Globalization and agrarian change: A case of freshwater prawn farming in Bangladesh. Journal of International Development I6(7): IOO3-IOI3.

Kooistra K, Termorshuizen A. 2006. The sustainability of cotton. Consequences for man and environment, Science Shop Wageningen University \& Research Centre. Report 223. ISBN: 90-6754-90-8585-000-2.

Laven A. 2009. Empowering rural entrepreneurs. The Broker. http://www.thebrokeronline.eu/en/Special-Reports/Special-report-The-power-ofvalue-chains/Empowering-rural-entrepreneurs. [I5 January 20II].

MacDonald K. 2007. Globalizing justice within coffee supply chains? Fair Trade, Starbucks, and the transformation of supply chain governance. Third World Quarterly 28(4): 793-8г2.

Magnus E, Steenhuijsen P. 20I0. Dealing with small scale producers. Linking buyers and producers. KIT Publishers: Amsterdam.

Markelova H, Mwangi E. 20I0. Collective action for smallholder market access: Evidence and implications for Africa. Review of Policy Research 27 (5): $62 \mathrm{I}-640$.

Muller C, Vermeulen W, Glasbergen P. 2009. Perceptions on the Demand Side and Realities on the Supply Side: a Study of the South African Table Grape Export Industry. Sustainable Development I7: 295-310.

Muller C, Vermeulen WJV, Glasbergen P. 20I2. Pushing or sharing as value driven strategies for societal change in global supply chains: two case studies in the British - South African fresh fruit supply chain, Business Strategy and the Environment 2I(2): I27-I4O.

Parikh T, Patel N, Schwartzman Y. 2007. A Survey of Information Systems Reaching Small Producers in Global Agricultural Value Chains. Information and Communication Technologies and Development http://www.stanford.edu/ neilp/pubs/ictd2007.pdf. [I5 December 20Io].

Parrish BD, Luzadis VA, Bentley WR. 2005. What Tanzania's coffee farmers can teach the world: A performance-based look at the fair trade-free trade debate. Sustainable Development 13(3): I77-I89.

Ponte S. 2008. Greener than Thou: The Political Economy of Fish Ecolabeling and Its Local Manifestations in South Africa. World Development 36 (I): I59-I75.

Porter M, Kramer M. 20II. The Big Idea: Creating Shared Value. How to reinvent capitalism — and unleash a wave of innovation and growth. Harvard Business Review. I-I7.

Prasad B, Dhar M, Roy S, Vamashi Krishna P. 2oio. Brochure More Sustainable Cotton Production. Cotton in India - Challenges and Opportunities to implement better cotton, WWF India.

Proctor FJ, Digal LN. 2008. Opportunities for small-scale producers' inclusion in dynamic markets in developing countries and transition economies: A synthesis of findings from eight country level chain-wide learning workshops. Regoverning Markets Working Paper. IIED: London, UK.

Ras PJ, Vermeulen W. 2009. Sustainable Production and the Performance of South African Entrepreneurs in a Global Supply Chain. The Case of South African Table Grape Producers. Sustainable Development I7: 325-340.

Ras PJ, Vermeulen W, Saalmink SL. 2007. Greening global product chains: bridging barriers in the north-south cooperation. An exploratory study of possibilities for improvement in the product chains of table grape and wine connecting South Africa and the Netherlands. Progress in Industrial Ecology - An International Journal 4(6): 40I-4I7.

Raynolds LT, Murray D, Heller A. 2007. Regulating sustainability in the coffee sector: A comparative analysis of third-party environmental and social certification initiatives. Agriculture and Human Values 24(2): I47-163.

Riisgaard L, Bolwig S, Ponte S, du Toit A, Halberg N, Matose F. 20Io. Integrating poverty and environmental concerns into value-chain analysis: A strategic framework and practical guide. Development Policy Review 28(2): I95-2I6.

Sadashivappa P. 2009. Bt Cotton in India: Development of Benefits and the Role of Government Seed Price Interventions. AgBioforum I2(2): I72-I 83 .

Schaub R. 20Io. Bayer CropScience's contribution to Sustainable Cotton Production. http://www.bayercropscience.com/bcsweb/cropprotection. nsf/id/DE_Sustainable_Cotton_Production/\$file/Sustainable\%2oCotton\%2oProduction.pdf. [I6 January 20II].

Seuring SA. 2008. Assessing the rigor of case study research in supply chain management. Supply Chain Management: An International Journal, I3(2): I28-I37.

Seuring S, Müller M. 2007. Core issues in Sustainable Supply Chain Management - a Delphi Study. Business Strategy and the Environment 2(7): I-I3.

Shiva V, Jalees K. 2006. Seeds of suicide. The ecological and human costs fos seed monopolies and globalization of agriculture. Navdanya: New Delhi India.

Shop for Change. 20I0. http://www.shopforchange.in. [23 February 20II].

Solidaridad. 20II. http://www.solidaridadnetwork.org/cotton. [26 November 20I0].

Textile Exchange. 20I0. 20I0 Farm and Fiber Report. http://organicexchange.org/oecms/Textile-Exchange-Publications.html. [8 March 20II].

Tirado R. 20I0. Picking cotton. The choice between organic and genetically-engineered cotton for farmers in South India. Greenpeace Research Laboratories and University of Exeter, UK, Greenpeace International. 
Valkila J, Nygren A. 2009. Impacts of Fair Trade certification on coffee farmers, cooperatives, and laborers in Nicaragua. Agriculture and Human Values 27(3): 32I-333.

Vermeulen W. 20I0. Sustainable supply chain governance systems: conditions for effective market based governance in global trade. Progress in Industrial Ecology, An International Journal 7(2): 138-162.

Vermeulen WJV, Kok MTJ. 20I2. Government Interventions in Sustainable Supply Chain Governance: Experience in Dutch Front-Running Cases, in Ecological Economics, 20I2. Forthcoming.

Vermeulen WJV, Ras P. 2006. The Challenge Of Greening Global Product Chains: Meeting Both Ends. Sustainable Development I4(4): $245-256$.

Vermeulen WJV, Seuring S. 2009. Sustainability Through the Market - the Impacts of Sustainable Supply Chain Management: Introduction. Sustainable Development I7: 269-273.

Vermeulen S, Woodhill J, Proctor F, Delnoye R. 2008. Chain-wide learning for inclusive agrifood market development: a guide to multistakeholder processes for linking small-scale producers with modern markets. International Institute for Environment and Development, London, UK, and Wageningen University and Research Center, Wageningen, the Netherlands.

Vermeulen WJV, Uitenboogaart Y, Pesqueira LDL, Metselaar J, Kok MTJ. 2oIo. Roles of Governments in Multi-Actor Sustainable Supply Chain Governance Systems and effectiveness of their interventions: an Exploratory Study. (Bilthoven, Netherlands Environmental Assessment Agency (PBL) and Utrecht University)

Yin RK. 2003. Case Study Research. Design and Methods. Sage Publications: Washington DC. 